Portland State University

PDXScholar

6-1-1966

\title{
"An approach to creative design" relation of composition to expression with a particular emphasis on color relationships.
}

Kay J. Moultrie

Portland State University

Follow this and additional works at: https://pdxscholar.library.pdx.edu/open_access_etds Let us know how access to this document benefits you.

\section{Recommended Citation}

Moultrie, Kay J., "'An approach to creative design" relation of composition to expression with a particular emphasis on color relationships." (1966). Dissertations and Theses. Paper 326.

https://doi.org/10.15760/etd.326

This Thesis is brought to you for free and open access. It has been accepted for inclusion in Dissertations and Theses by an authorized administrator of PDXScholar. Please contact us if we can make this document more accessible: pdxscholar@pdx.edu. 
" AN ARPROACH TO CREATIVE DES IQN" RELATION ON COMPOSITION TO EXPRESSION WITH A PARTICUAAR EMPHASIS ON COLOR RELATIONSHIPS.

by

KAY J. MOULTRIE

\author{
A THESIS \\ submitted to \\ PORTLAND STATE COLHEAE
}

In partial fulfiliment of

the requirements for the

degree of

MASTER OF SCIENCE

June 1966

PORTLAND STATE COLLEGE LIBRARY 
PAINT LNGS

d. "City-scape" No. $i$.

2. "City-scape" No. II.

3. "Mother and Child"

4. "Yellow-11ght"

5. "flight"

6. "Moon Flowers"

7. "The Band"

8. "flowers"

9. "Drops"

10. "rlowers"

11. "Rhythme foverant

12. "City-scape" No. III

13. "The Covered Bridge" $22^{n} \times 24 "$

$12 "$ × 2.4"

$16^{\prime \prime} \times 20^{\prime \prime}$

$12^{\prime \prime} \times 16^{\prime \prime}$

$14^{n} \times 24^{n}$

$16^{11} \times 20^{* 1}$

$16^{\prime \prime} \times 20^{\prime \prime}$

$20^{\prime \prime} \times 30^{\prime \prime}$

$16^{\prime \prime} \times 20^{n}$

$18 " \times 24 "$

$22^{\prime \prime} \times 22^{*}$

$12^{\prime \prime} \times 24 "$

2. $\times 31$

All photographs unless otherwise 1 isted were taken with Phototrix $25 \mathrm{mg}$ camer using Kodacolor film and Plus $X$ for the black and white prints. 


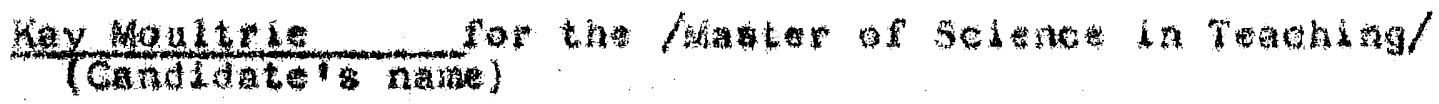
Data these is protontod 19x 1966 (1)

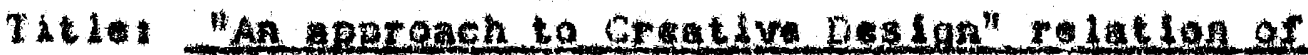

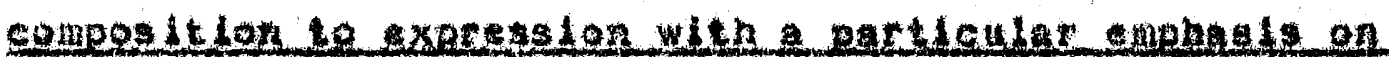
color relationahips. Abstract aprouret:

The in concentrathon of otudy for my project was

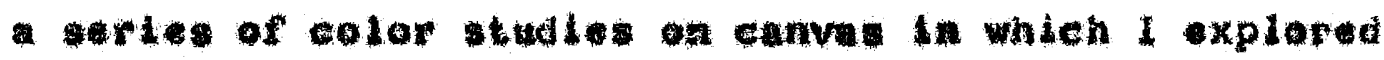
Varyting aroportons of primary color mixtures, unfamilier color nethondhips and tue ranges. i was particularly

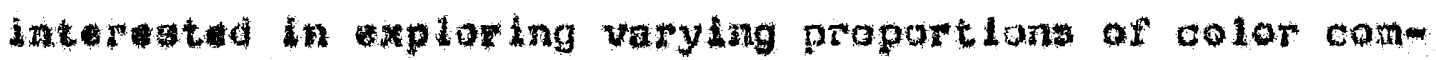
plemantara in working to achiave noutrata. Throughnout my studiea i worked for a unity un the sequences af color mixtures. For mart of py project 1 wowled with coilage ratorials, when wo aubordintad to color but ralesod

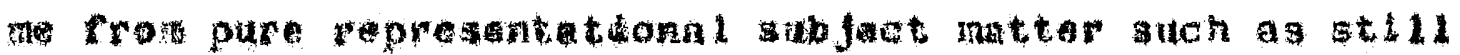

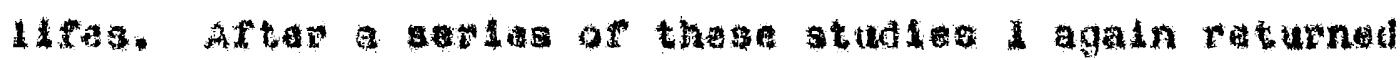

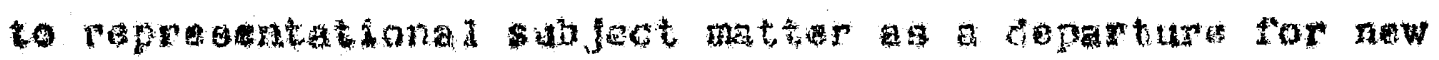

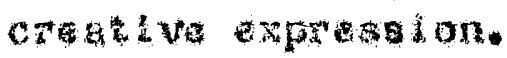


APPNOVID

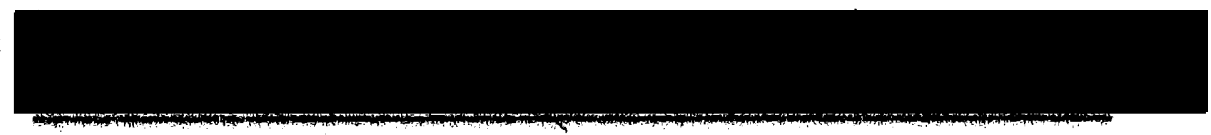

The Le Adviser

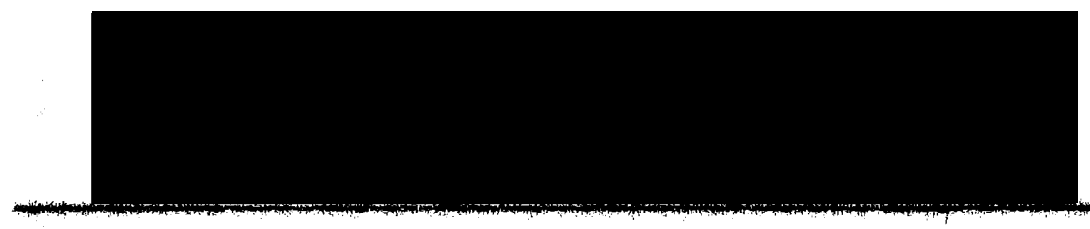

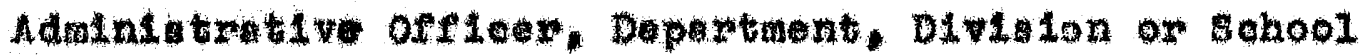

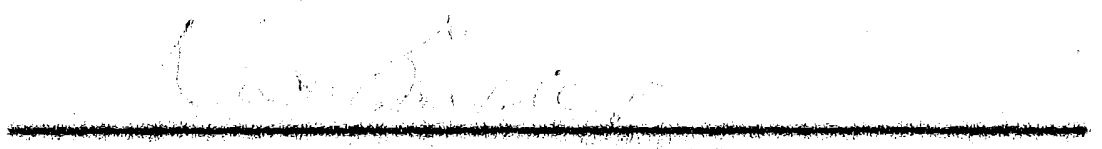

Fow the aratude counell.

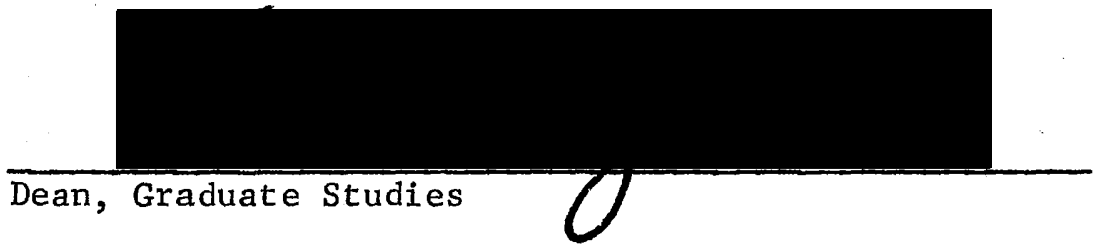

Date thes 18 proventodt $4 a x 4,1966$ 
"An approach to Creative Design" relation of composition to expresalon with a particular emphasis on color relationships.

The ma in concentration of study for my project was - series of color studies to explore varying proportions of color mixtures, unfamillar color rolatlonships, value ranges and to work for anity or tonallty through these color combinations and rolationships. I did some research on collages and found these most exclting. 1 declded to do a serles of collage palnting, whleh would be subordinated to color but would release me from pure representational subject mater such as otil1 lifes.

I have a partleular affinity for geometrle shepes and I was drawn to the work of Mondrian. I was Interested In his worke partleularly where he reduced man made structures to theip purest form, which resulted In geometric squares and rectangles to convey landscape. Mondrian was in turn Influenced by the cublst movement and from previous studies, I was also influenced in the knowledge that palnting coutd have life of lts own. The greater the departure from the subject resemblance, the clearer the dynamic quallties of the plestle forces, such as the expressionistle quality of color. Also at this time I did a sudy on the works of Paul kles. These studies were to influence the direction 
my color studles would itinately take. I observed that Klee was able to show through his wo rks that contrasting expression could be obtaingd by the very exstensive employmont of 11 the tones from black to white or the employment of the lower register, whlch was deep and sombre. He literally invented color relationships through experimentIng exhaustively with all posstble varlations of color withIn set ifmlte. He produced color combinations which were inumerable. Many of his compositions were created through h manipulating inventiy varied shapes, colors and rhythms lone and to these I paid partioular attention. To mention a few which I was influenced by "Fugue in Red", in 1921 in watercolor, "Intenslflcation of color from the static to the Dynamlc", 1920 in o11, "Yellow signs", 1937, "Garden in Bloom", 1932 in 11 and "Captive Plerret", 1923 in o11. Under these varying influences I began my studles. For the collage materials I chose a rather 1 inlted range of materials for textural erfect (gauze, burlap, corrugated paper, and canvas) but each dld have a distinct textural quality and novement from smooth to rough. I did several studies of cltyscapes and worked to combine reduction of the clty to baslo geometric shapes and at the same time glve a follng of the textural qualltios of the various bullding surfaces you would find in the city. I adhered these shapes with gesso which I found preferrable to Elmer's 

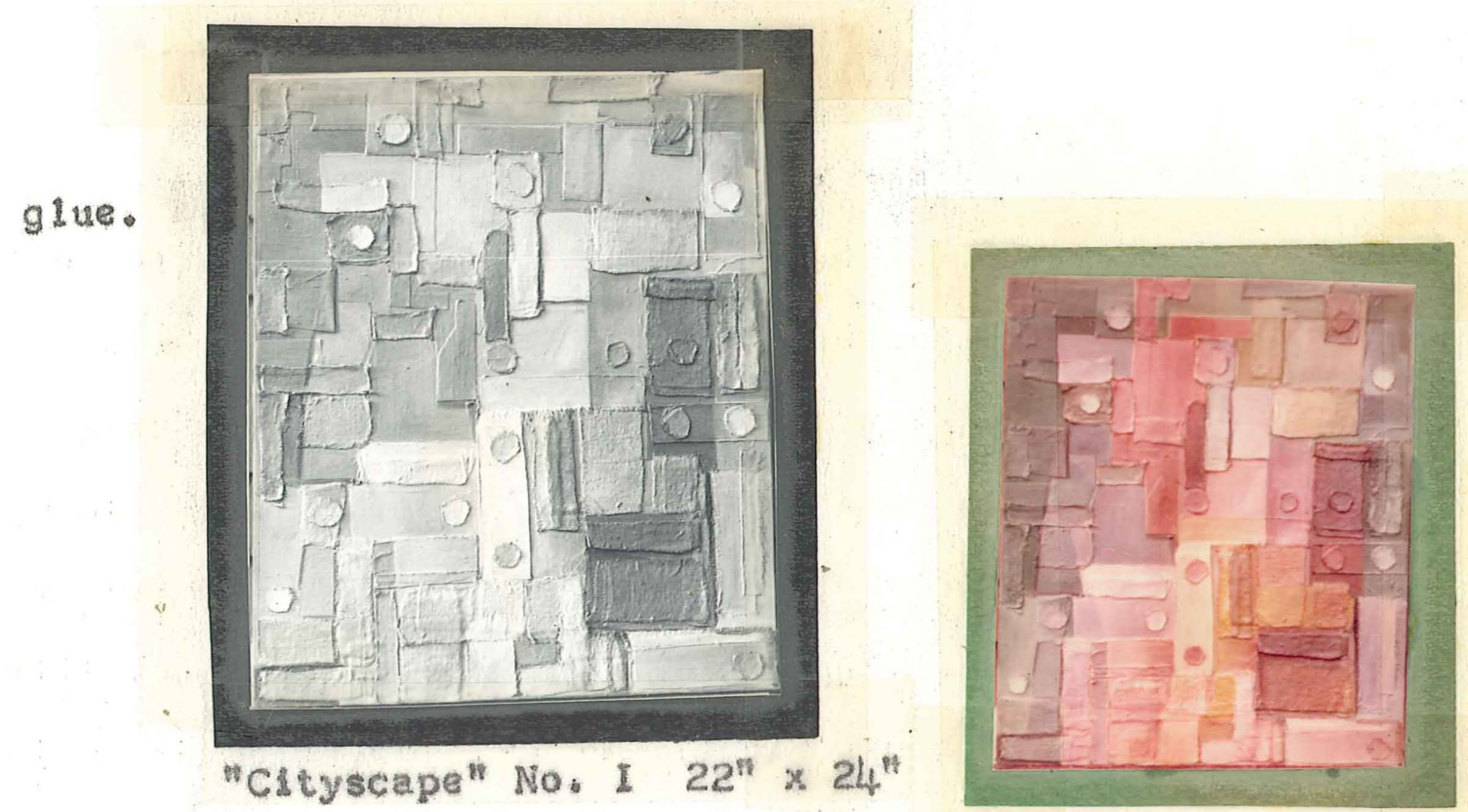

This is the fouth painting on this particicir canvas which was not reworked in succession but by returning after working on other canvases and after gaining other insight into my work. I regret I da not photograph the various steps. Observations from my tist canvas was a lack of tonality, a unity of total color impact. I had choosen to paint the irst canvas with a green hue but the resulting Pourth canvas was divided vertically into four hue areas. To each basic color $l$ added varying proportions of other primaties on the colog wheel. In some areas I added complementaries together to achieve neutrals. By adding complementaries I achieved varied color sequences. Another consideration soon became apparent, that of the absorption sate of the various collage materials and how absorption affected the brillancy of the color.

At this time I began a new evaluation of color fundamentals which had considerable influence upon my later works. 
I became familiar with Edwald Hering's theory that all hues and mixtures could be derlved from the four coupled colors, red-green, blue-yellow plus black and whlte. I also studied Munsell's, Ostwald's and Prang's color systems. Also the works of Paul kiee as previously stated were of considerable influence upon me. I was able to preceive a whole new dimension of color in reference to my own color appreciation and use.
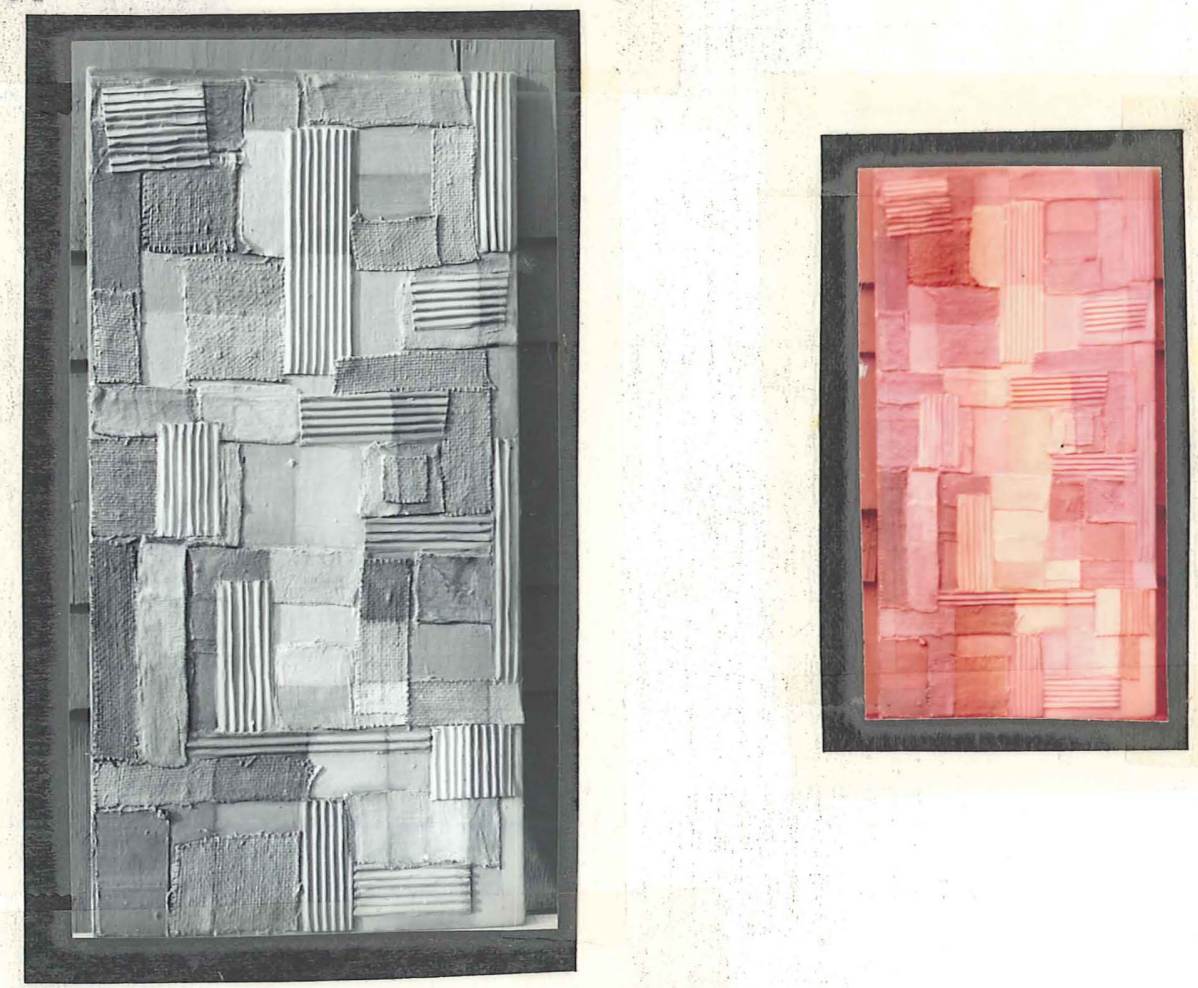

"C1tyscape" NO. II $12^{\text {t }} \times 24$ "

1 began this canvas following the same steps as in the first canvas, only this time I worked for a red-orange dominance. To red I added varying proportions of orange 
and blue to achleve subtle changes whlch in turn $\mathrm{mplled}$ movement as sun eleeting over the city. A warm sun that sortens the harshness of the clty and gives the city a feeling of warmth. I observed how the pigment red lost. It's brillancy in terms of the amount of color lower in the scale that was added to it. Through subtle changes there is both a vertical and hortzontal movement, but not to the point of destructive movement, but one of unity. I feel that this is a successful palnting whth a good tonallty. The red-orange is in medium value range and follows the natural order of values. I selected the value of the hues used together in the same order of value that are found on the value scale.
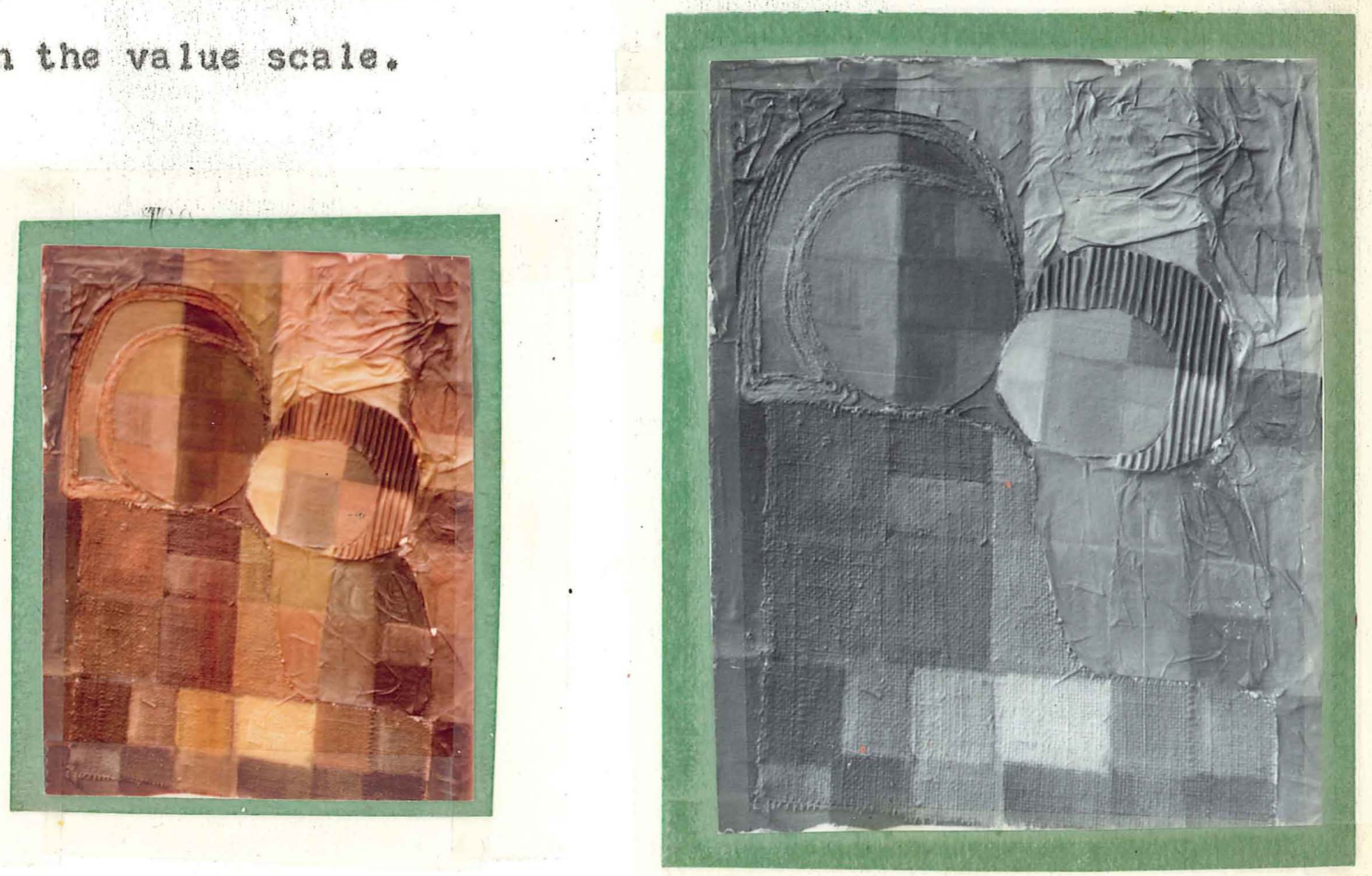

"Mother and ChI1d" $16^{\prime \prime} \times 20^{\prime \prime}$

1 began the canvas following the same baslc steps as 
In the inst two canvases. But this thme I wished to couple colot studlas with the thage of form, making the bight suggestion of the form of a nother and child. 1 also experinented whth the manipulation of paper towe 1 Ing in gesso. I worked to subordinate the forms to color and 1 chose the hue green anticlpating that grean denotes If and Iring things and mother child symbollaes the aternal recreation of iffe. Subtle changes were achaved by adding varying proportons of orange, yellow and blue to green. Color movenent exists on both verticalhor 1 zontal planes emphas zed by dividing the carvas area Ento squares of various colon combinations. I see that this is a successiul painting. This Is the secand painting on this canvas, previous 1 y $I$ had chosen blue as the dominatIng hue and form tended to dominate color sequences. The resulting painting has a pleasing tonallty, is in low key and follows the natural order of values.

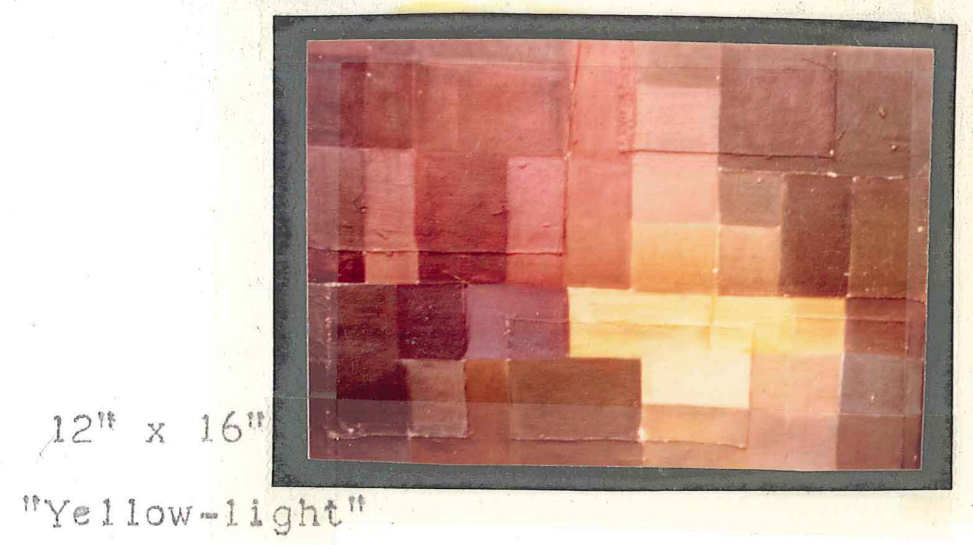

I applied only one material that of canvas to give a 
slight sensation of textural depth. I divided the canvas into pur dominant hue areas those of red, orange, blue and green, This palnting is sombre, in low-key with very subtle changes. It was interesting to observe how yellow-green was affected by surrounding color areas and how movement was created by these surrounding areas converging upon the yellow-creten grea.

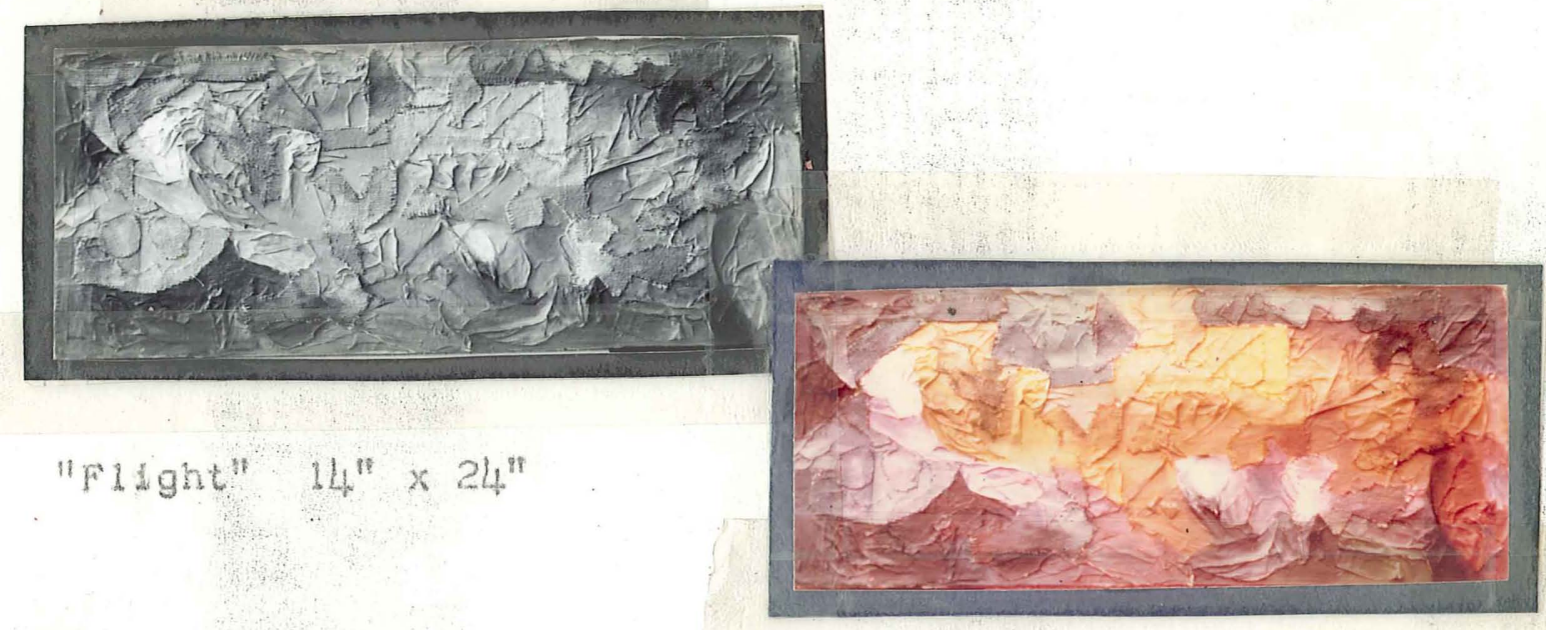

On this particular canvas I changed my approach by not reduchng the collage materlals to geometric shapes but was interested in more freedom of materials and movenent. I took paper toweling and manipulated the toweling with my hands, to create greater movement snd rougher surface texture. These textural diualitis wer again subordinated to color relationships and this is the second palnting on this canvas 1. chose the basic colors of green, orange, red, blue and yellow and worked for a movement of those hues across the canvas from lept to right. I added white to tne various 


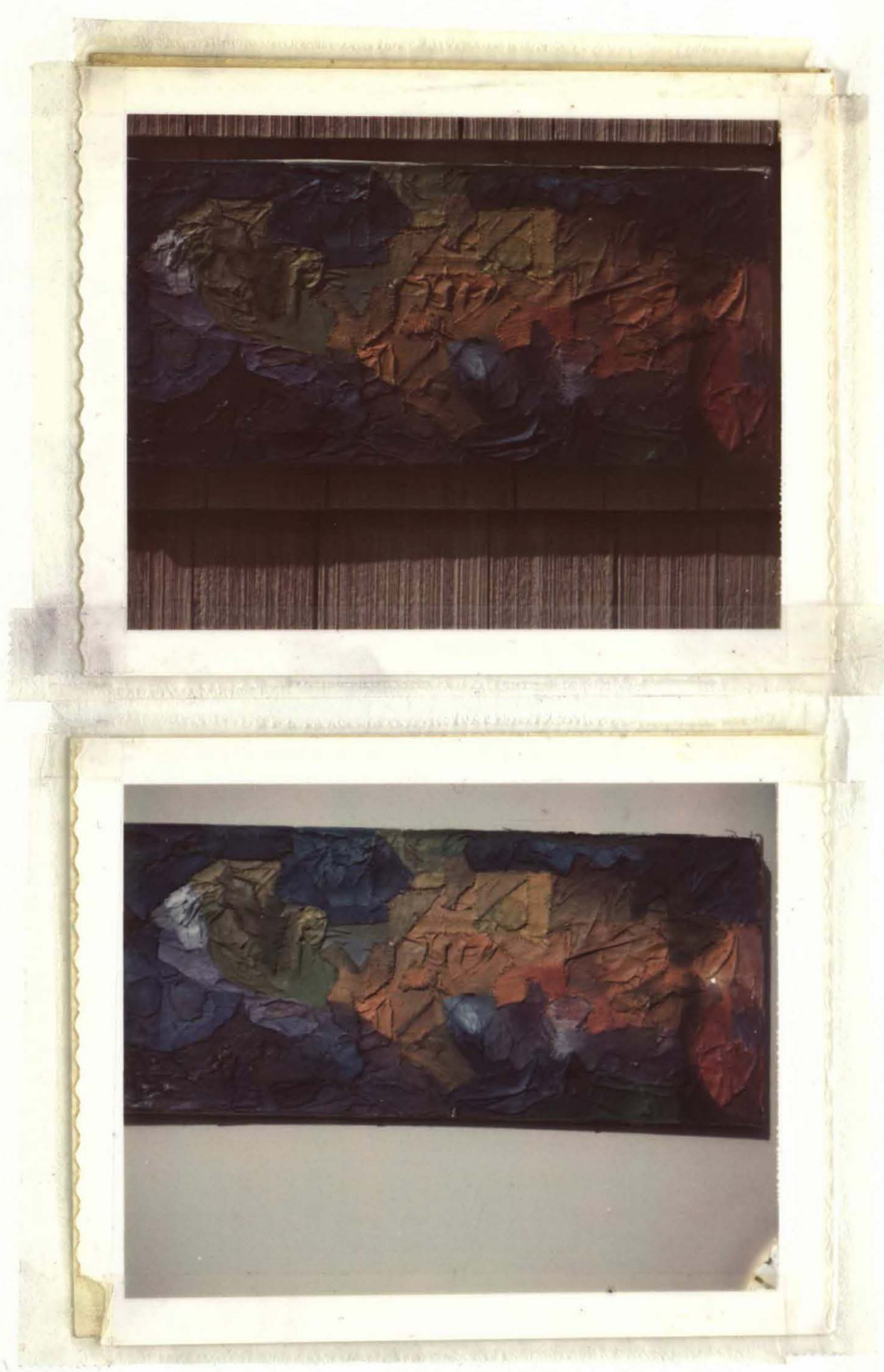

These photographs were taken with a Polorold Land Camera, No.900 using type $48 \mathrm{film}$ and in full sun. I included both of these photos because of the differences, one showing the textural effect better and the second nearer a true reproduction. 
color and no where in this canvas does color exist as pure colot. The resulting painting is one of mediun key with several neutral areas and 1 feel a pleasang color movement.
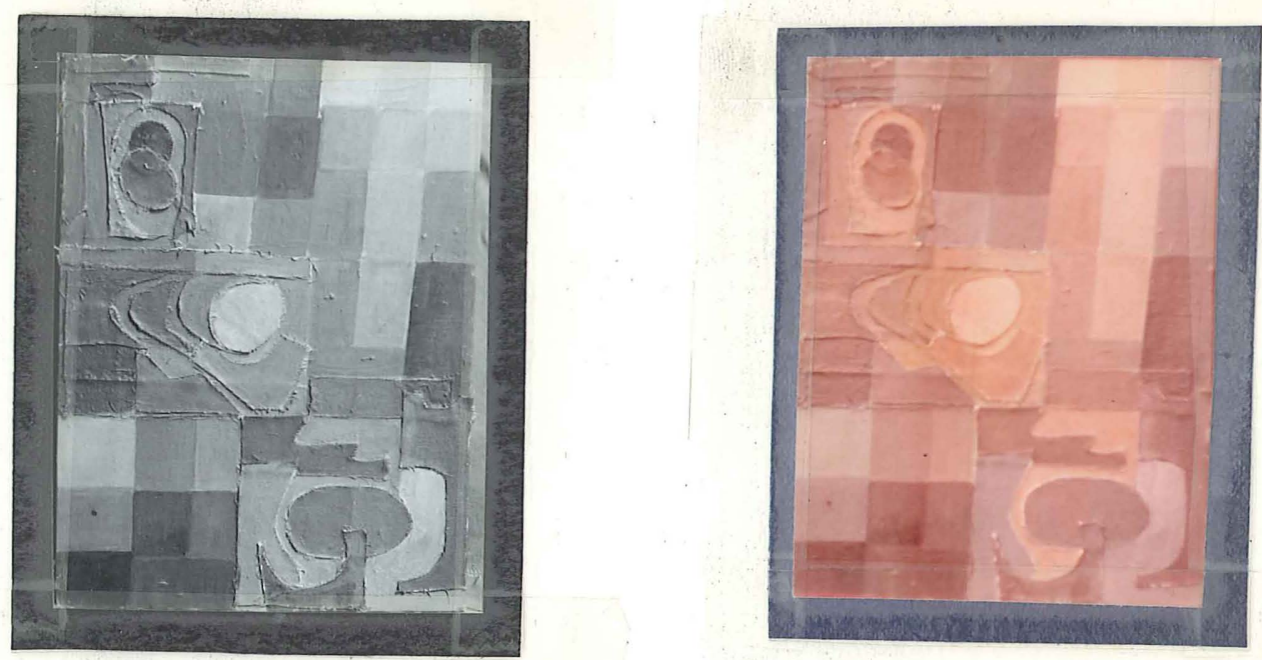

"Moon Flowen"

$16^{m} \times 20^{19}$

This time I became more interested in circular geometric shapes and arregular edges of the collage materials. I did not adhere materials to the whole surface area but worked in a vertical movement with the materials and form. I broke the gest of the canvas into squared areas where 1 worked out my color sequences. The dominant hue of this painting is blue. I added varying proportans of yellow orche and green to blue to achieve subtle changes which led to movement of color. I feel this painting has a good tonality or unity and is a successful painting. 


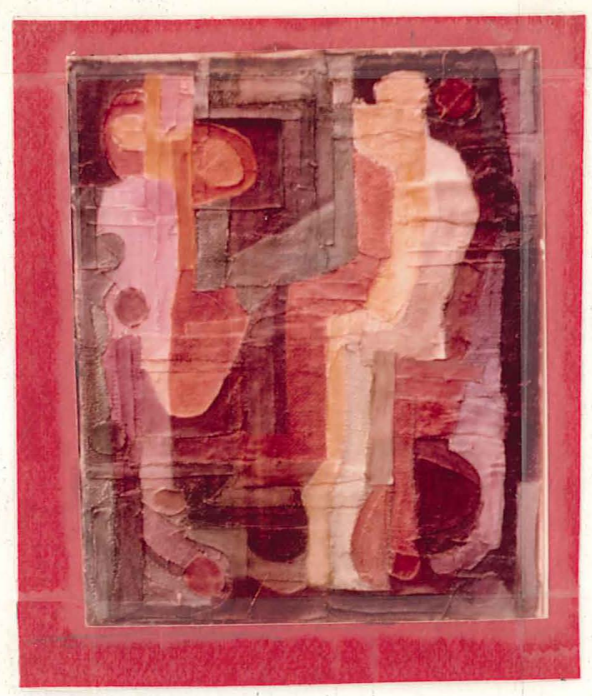

"The Band"

$16^{\mathrm{*}} \times 20^{\mathrm{n}}$

This is the second painting on this canvas. The first was a siudy in blue whth red added in varying proportions and the resulting painting was displeasing in th lack of movement and tonality. This canvas was approached as a collage color study whth an increased textural depth budit up with layers of material. My second painting was an attempt to suggest human form through vertical hue movement. By adding white to primary colors I produced tints which wers emphasized by shades in smaller areas. There is a feeling that the collage materials might have been denied to such and extent thet the results are displeasing. 

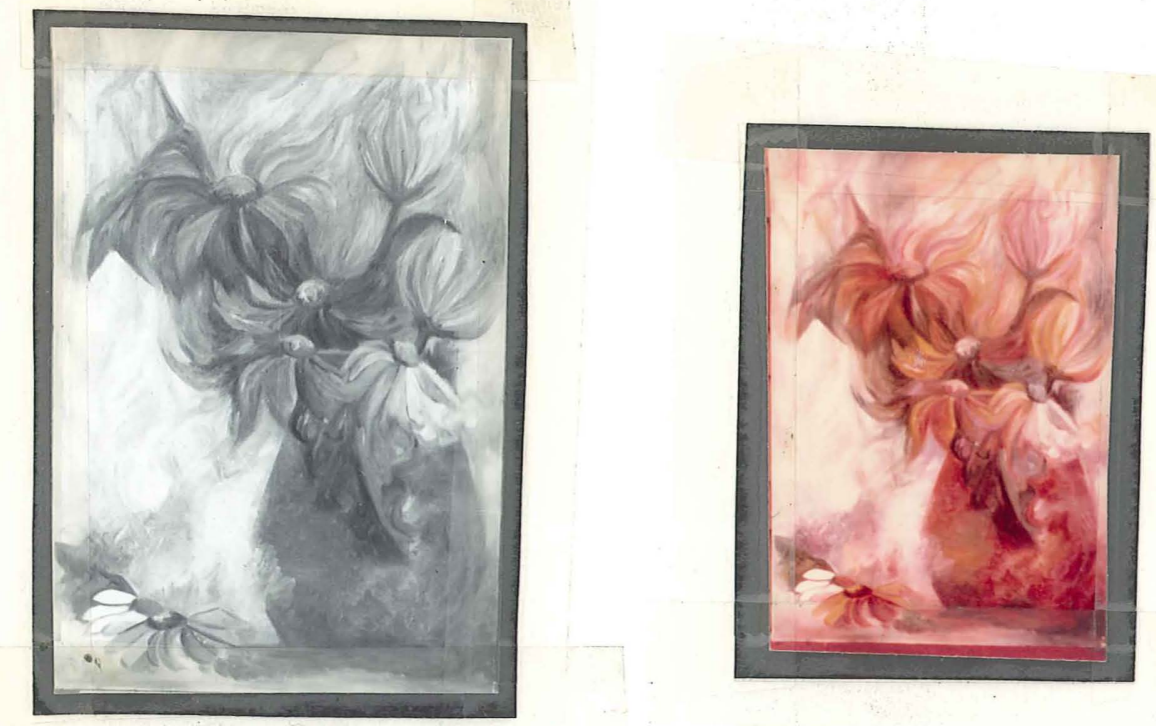

"Flowers" $20 " \times 30^{n}$

At this time I reburred to flowers for study. I dad a series of pencil sketches to work for the feeling and wovement of the flowers. Through previous studies I was able to use color in a more arbitrary sense. The primary reasonfor this kind of departure is the increase in emotive power which these departures furnish. I was not basically interested in form but only as a departure from which to work and axperiment. I used the fult range of the color wher 1, red, orange, yellow, green, blue and worked for tonality, unity of color impact. I had to work to keep the colors in the dr proper spatial plane, knowing that warm coloss advance and cool recede. Colors shint in hue and value relative to the hue and value of surrounding color and I feel this painting is very successful in that respect. Light source also had to be considered, a 


\section{$10-a$}

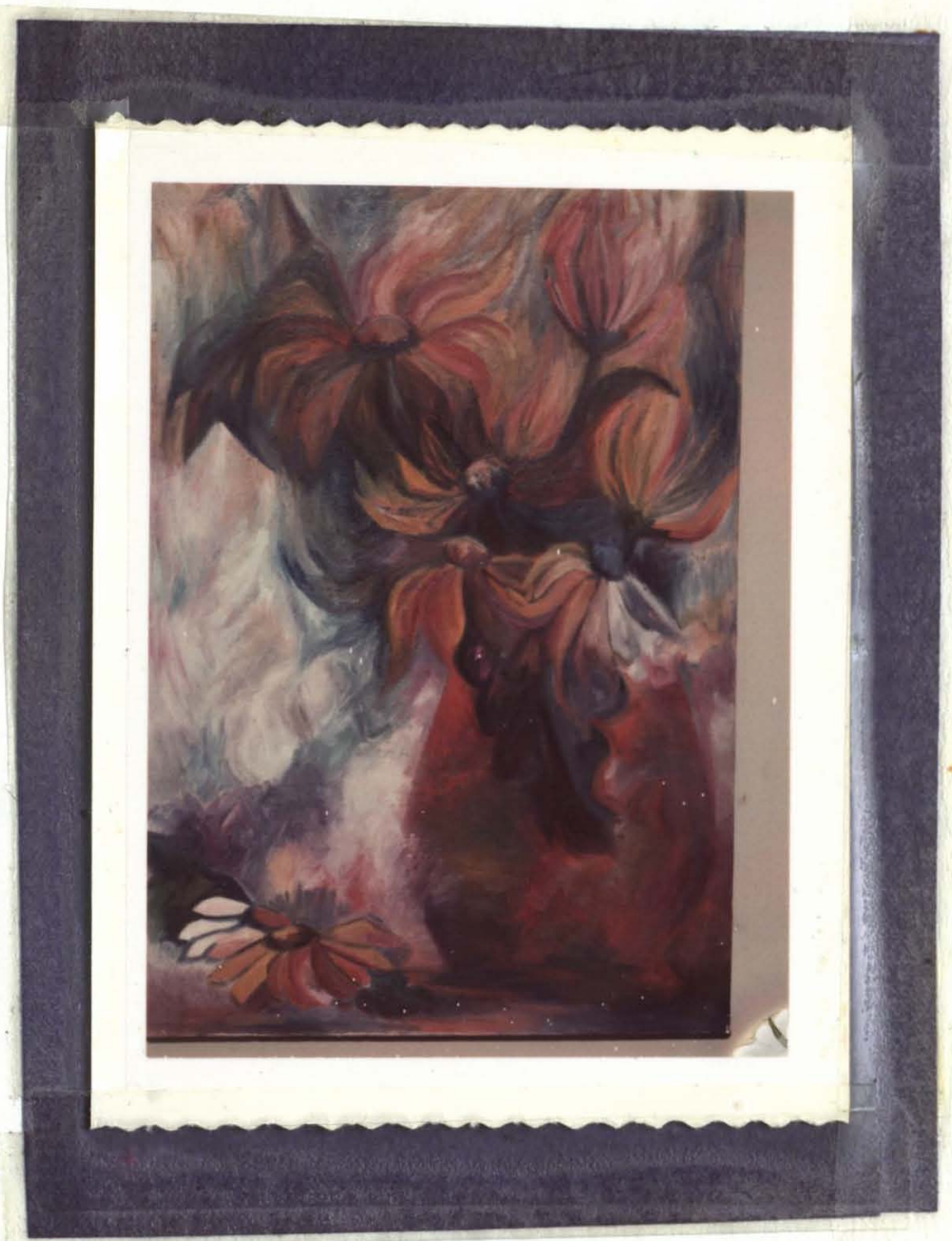

$$
\text { "Flowers" } 20 " \times 30 "
$$

This photograph was taken with a Poloroid Land Camera, No. 900 using type 48 film. 
each color reflects a variety of wavelenghts. I made a side trip in my studies in studying the various wave lenghts of the promery hues. In thas panting 1 have red which has the longest and blue which has the shorest, but since pigments are neutnal 1 zed by adding complementary colors they are in harmony with each other. By adding complamentary colors I subtracted from each other's wave length. Through-out my studies it was interesting to observe how the eye records and creates effects, such as after-images, color fringes, and Visual mixtures of color" Works by Seurat, Van Gogh, Gauguin, Plcasso and Renian were influencial in studying color.

Color hamony can not be controlled by tulps but a fundamental understanding of color is essential. A painting that afrects the eye and mind agreeably is successful. Color harmony uncludes inity, consistency and sthness. I feel that through these various studies I made a real advancement in my use or color and creative expressionalism.
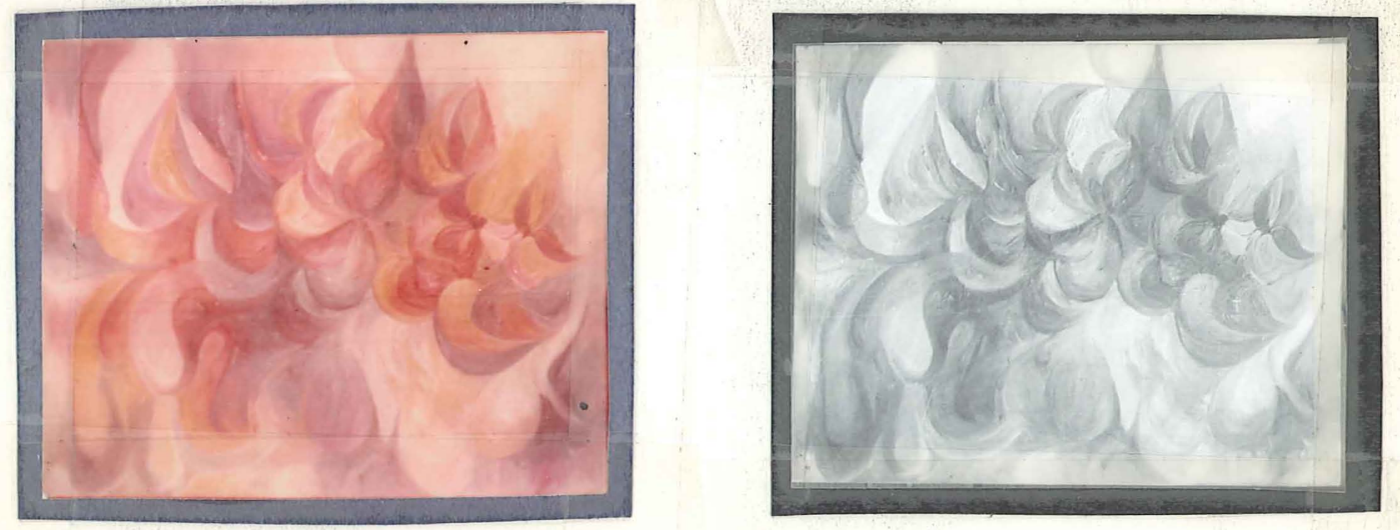

$$
\text { "Drops" } 16 " \times 20 "
$$


This is the second painting on this canvas. The first was a stuay of dasses, and from it evolved this painting. From the movement of flowers I derived a feeling of the nature and growth of the rlowers. I ussd color arbitararily working whth primary colors to produce intermediate or secondary colors. Then i used complementary colors to produce neutrals, but did not work for a complete neutralization, but to lower the values and retain basic hue areas. I feel this is a successful painting with good value relationships and tonality.
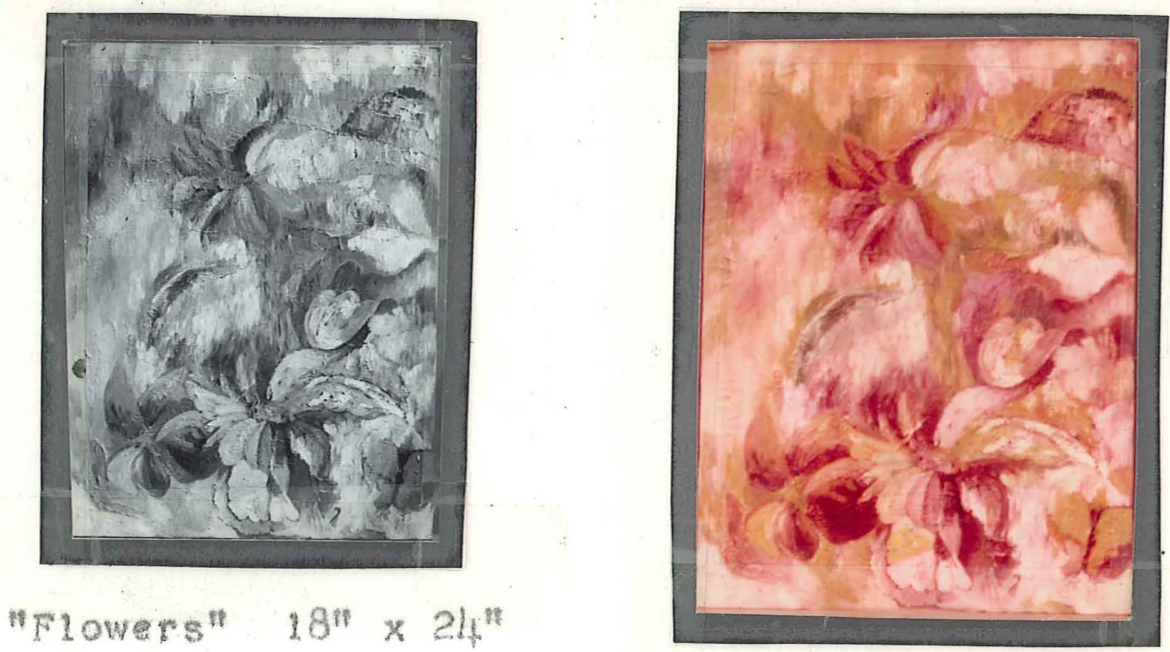

rhas is the second panting on this canvas and the subject I departed from was zinnas. This time I worked for a higher-keyed painting, applying pigments closey in itspure colors. I worked for color movement throvghmout the painting. I added white to the pigments producing thits and I worked for a few complementaries to produce several relatively small neutral areas. The colorsare 
cool warn.

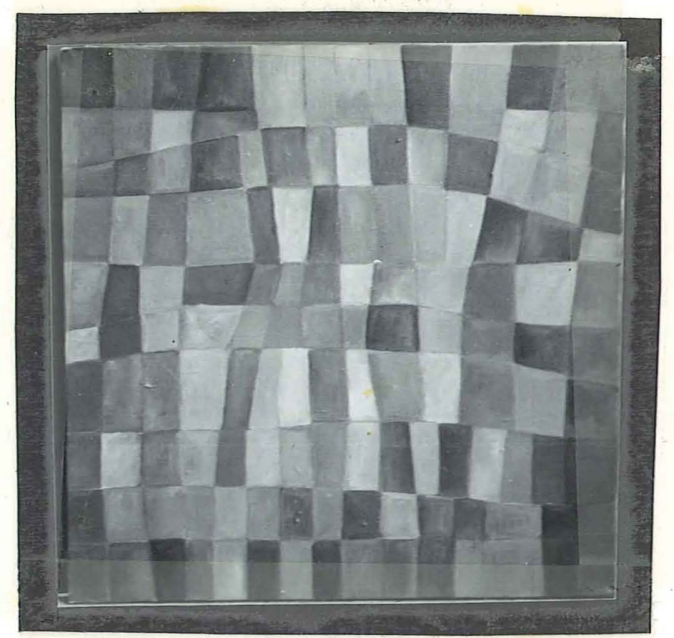

"Rhythmic Movement" $22 " \times 22^{\text {" }}$

This palnting is divided into rectengular areas, 1 advolded static stralght dgas and gave movement to the edges of the rectangular areas by varying the angles of the edges. From primary colors, ged, yellow and blue, 1 experiemented with adding varying proportions of color in each rectangular area to achivve varying color sequences. I worked fos a vertical-horizontal movement, notlcing how cach rectangular areas was In turn incluenced by surroundIng color areas. 1 find this panting pleas movement and unity. 


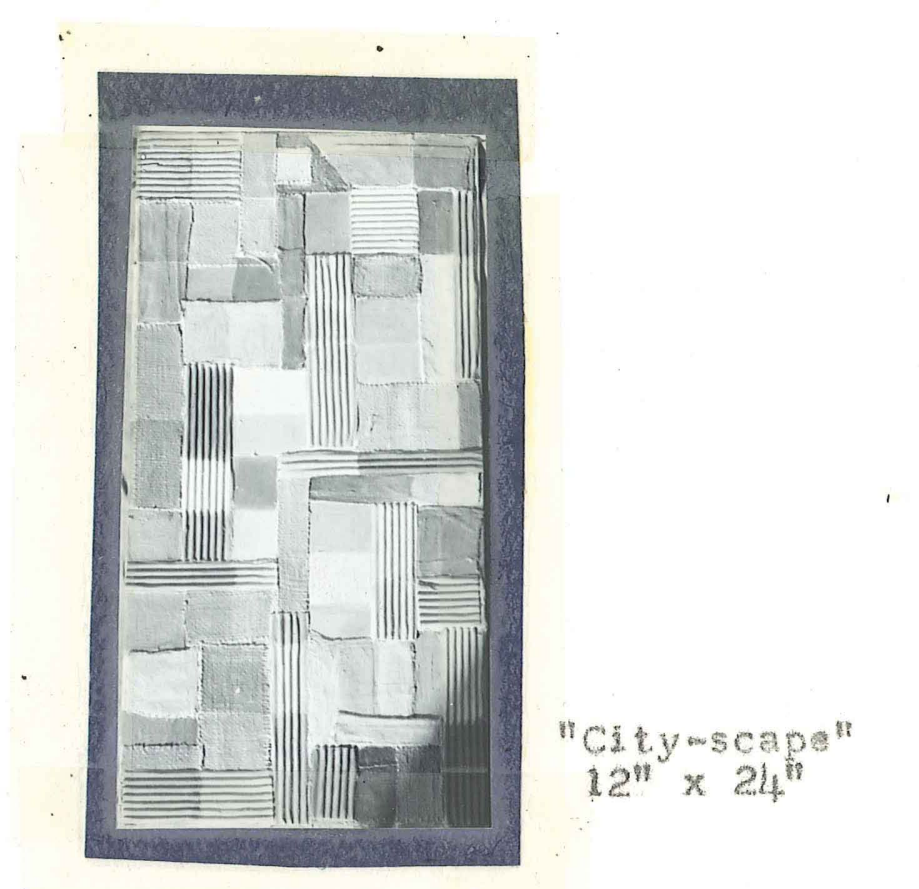

$I$ adhered materdals as before in my collage studids. On this canvas 1 chose the complementary colors orange and blue, and by addung varying proportlons of blue to orange 1 achisved a sequence of brown ranging in dominant hue from

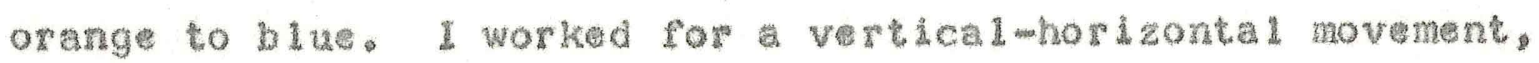
subordunating collage materials to color 1 divided the canvas Into four areas, weh area having dominat hue. Moving through-out the center of the canvas on a vertcal plane is a sequence of squares in which I maked varying proportions of yel low to ether orage or blue. I feel this is a successrul patring with good tonality. 


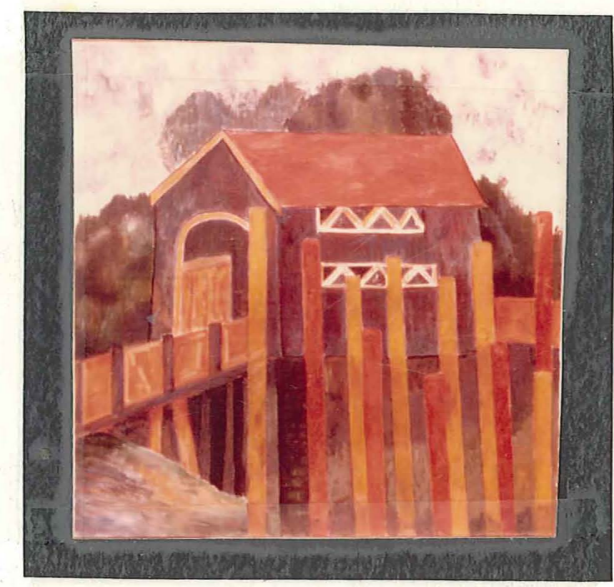

"The Covered Bridge" $2^{1} \times 3^{1}$

Through exploration in the various color studies I have ganed further ing ight into color mixtures, value relationships, value ranges and particularly a new and exciting area for creative expression. Included is a painting, "The Covered Bridge", Pinished previous to my work on the color project and by compardson I can see a real advancenent in the tonality and color relationships in the work I have recently completed. 


\section{BIBLIOGRAPHY}

I. Abott A. J. The Color of Life. Mc Graw, 1949.

2. Birren, Faber, Color, Form, Space. Reinhold, 1961,

3. Birren, Faber, Creative Color, Reinhold, 1961 .

4. Birren, Faber. History of Color in Painting, Reinhola, 1961.

5. Cheskin, louis. Notations on Color systems. Color Research Institute of America, 1947.

6. Di San lazzaro, G. Klee. Praeger Pub, New York, 1957.

7. Graves, Maithiand. The Art of Color and Design. Me Graw, 1956.

8. Graves, Maithland. Color Fundamentals, Mc Graw, 1952.

9. Coldwater, Robert John. GauguIn. Abrams, 1957.

10. Gupt11, Arthur. Color Manual for Artists. Reinhold, 1963.

11. Hulton, Nike. An Approach to Paul klee. London, Phoenix House, 1956.

12. Huyghe, Rene, Gauguin. Crown Pub., New York, 1959.

13. Janis, Harriet and Blesh, Rudi. Collages, Personalities, Concepts, Technlques, Chilton Co., New York, 1962.

14. Jacobsen, Egbert. Basic Color, an Interperation of the Ostwald's Color System. Theobald, Chacago, 1948.

15. Kepes, Gyorgy, Language of Vision. Theobald, Chicago, 1964.

16. Klee, Paul. The Inward Vision. Tr. by Norbert Guterman. Abrams, 1959.

17. Klee, Paul, Pedagogical Sketchbook. F. A. Praeger, 1953. 
10. Loran, Erle. Cezanne's Compositions. University of California, Barkley and Los Angeles, 1963.

19. Mellach, Dora 2. Collage and Found Art. Muhold, 1961.

20. Renner, Paul, Color, Order, Harmony, Relnhold, 1965.

21. Rewald, John. Gauguin. Hyperion Press, 1949.

22. Sargent, Walter. The Enjoyment and Use of Color. Dover, 1964 .

23. Seyphor, Hiche1, Plet Hondrian life and Work, Abrams, 1956.

24. Taylow, F, A, Color Technology. London,Oxford University Press, 1962. 